\title{
ECOTYPIC VARIATION IN GROWTH AND SURVIVAL TEMPERATURE OF CLADOPHORA VAGABUNDA (CHLOROPHYCEAE) ISOLATES FROM DIFFERENT CLIMATIC ZONES
}

\author{
by
}

AGUS M. HATTA ${ }^{1)}$ and AM BREEMAN ${ }^{2)}$

\begin{abstract}
The effect of temperature on relative growth rates (RGR) and the ability to survive at stress temperatures have been investigated in isolates of the green algal species Cladophora vagabunda from Roscoff (Eastern Atlantic, temperate), Corsica (Mediterranean, subtropical), Western Australia (Indian Ocean, subtropical) and Curacao (Western Atlantic, tropical). Growth was observed between $10^{\circ}-35^{\circ} \mathrm{C}$, except in the Roscoff isolate which grew between $10^{\circ}-30^{\circ} \mathrm{C}$ and a temperature of $5^{\circ} \mathrm{C}$ was too low for growth in all isolates. Those indicate that all isolates were comparatively eurythermal. Variations in RGR were observed with a high maximum RGR in the W. Australian and Roscoff isolates with ca. $74 \%$ increase in length per day at $30^{\circ} \mathrm{C}$, and a lower maximum RGR in the Corsican and Curacao isolates with ca. 30-50\% increase in length per day at $20^{\circ}-25^{\circ} \mathrm{C}$. The broadest optimum range (between $15^{\circ}-30^{\circ} \mathrm{C}$ ) was shown by the Corsican isolate and the narrowest optimum range (between $25^{\circ}-30^{\circ} \mathrm{C}$ ) by the Curacao isolate. At a low stress temperature of $0^{\circ} \mathrm{C}$, all isolates survived for at least 30 days without damage, after 30-50 days the Roscoff and Curacao isolates showed damage (cell bleaching) but they recovered at $20^{\circ} \mathrm{C}$. The $\mathrm{W}$. Australian and the Corsican isolates survived undamage for 60 days. At a high stress temperature of $35^{\circ} \mathrm{C}$, the $\mathrm{W}$. Australian and the Curacao isolates survived for 60 days, but the other two isolates died within 30 days. The different temperature responses of the isolates demonstrated the ability of Cladophora vagabunda to exist in varied temperature environments.
\end{abstract}

\section{RINGKASAN}

Penelitian pengaruh suhu terhadap kecepatan pertumbuhan relatif (KPR) serta kemampuan hidup dalam suhu stres pada rumput laut hijau Gadophora vagabunda dari berbagai isolat telah dilaksanakan. Isolat-isolat tersebut berasal dari berbagai regim geografi yang sangat berbeda, yaitu dari Roscoff (Perancis Utara, Atlantic Utara, beriklim dingin), Corsica (Perands Selatan, Mediterranean, beriklim subtropis), Australia Barat (Samudera India, beriklim subtropis) dan Curacao (Nederland Antillen, Atlantik Barat, beriklim tropis). Pertumbuhan berlangsung dalam selang suhu antara $10^{\circ}$ $35^{\circ} \mathrm{C}$, kecuali pada isolat dari Roscoff yang tumbuh dalam selang suhu antara $10^{\circ}-30^{\circ} \mathrm{C}$. Suhu $50 \mathrm{c}$ ternyata terlalu rendah bagi semua isolat untuk bisa tumbuh. Hal ini menunjukkan bahwa semua isolat adalah bersifat euritermal. Terdapat variasi KPR ciimana suatu KPR maksimum yang tinggi terjadi pada isolat dari Roscoff dan Australia Barat, yaitu sekitar $74 \%$ penambahan panjang tanaman per hari dalam suhu $30^{\circ} \mathrm{C}$, sedang KPR maksimum yang rendah terjadi pada isolat dari Corsica dan Curacao, yaitu sekitar $30-35 \%$ penambahan panjang tanaman per hari dalam suhu antara $20^{\circ}-25^{\circ} \mathrm{C}$. Kisaran pertumuhan optimum yang lebar diperlihatkan oleh isolat dari Corsica (berlangsung dalam suhu antara $15^{\circ}-30^{\circ} \mathrm{C}$ ), sebaliknya isolat dari Curacao memperlihatkan kisaran pertumbuhan optimum yang sempit (antara $25^{\circ}-30^{\circ} \mathrm{C}$ ). Dalam suhu stres rendah $0^{\circ} \mathrm{C}$, semua isolate

1) Research and Development Centre for Oceanology-LIPI, Ambon, Indonesia.

2) Dept, Marine Botany, BioL Centre, State Univ. Groningen, P.O. Box 14,9750AA Haren (Gr.). The Netherlands. 


\section{HATTAand BREEMAN}

mampu hidup paling tidak selama 30 hari tanpa adanya kerusakan sel, setelah 30-50 hari isolat dari Roscoff dan Curacao menunjukkan tanda-tanda kerusakan (hilangnya pigmen sel) tetapi mereka berhasil tumbuh kembali dalam suhu $20^{\circ} \mathrm{C}$. I solat dari Australia Karat dan Corsica bertahan hidup tanpa rusak selama 60 hari dalam suhu stres rendah tersebut. Dalam suhu stres tinggi $35^{\circ} \mathrm{C}$, isolat dari Australia Barat dan Curacao mampu hidup selama 60 hari, tetapi kedua isolat yang lain mati dalam 30 hari. Perbedaan respon suhu dari keempat isolat mondemonstrasikan adanya kemampuan strategi Qadophora vagabunda untuk hidup pada berbagai variasi lingkungan suhu.

\section{INTRODUCTION}

Based on the general term of ecotype, which was defined by Turesspn (1922, In : GREGOR, 1944), the ecotype nature of variation between populations of one species must be determined by conducting experiments under common laboratory conditions (ESPINOZA and CHAPMAN, 1983; INNES, 1984). Experiments to find temperature ecotupes in marine algae have been conducted with Ectocarpus siliculosus (BOLTON, 1983), Laminaria longicrusis and L. Saccharina fBOLTON and 1DNNING, 1982). Dumontia contorta f RIETEMA and VAN DEN HOEK. 1984) and Cladophora albida (Cambridge et al, 1984). Some species showed genetically based variations in temperature responses but the others did not show such variation. Thus, they can not be refered to as ecotypes. However, in widely distributed marine algae, one might expect variations in temperature responses which are controlled by genetic factors between populations from different temperature regimes.

Cladophora vagabunda has been reported by VAN DEN HOEK (1979) in the northern hemisphere of the Atlantic Ocean, and by VAN DEN HOEK and Womersley (1984) in the Eastern Indian Ocean. Thus, $C$ vagabunda is a widely distributed marine a?ga? which occurs from tropical to temperate zones. The habitat range of this species thus includes environments with widely differing temperature, ranging from ca. $30^{\circ} \mathrm{C}$ in the tropical waters down to ca. $-1^{\circ} \mathrm{C}$ in the northnern waters (Cambridge et al, 1984).

The present study involves the determination of optimal temperature for growth and the survival at stress temperature of strains of $C$. vagabunda collected from sites with very different temperature regimes, in order to investigate whether the success of the species is achieved by the extremely urythermal nature of all strains, or by the evolution of ecotypic variation over this wide geographical and environmental range.

\section{MATERIALS AND METHODS}

Four isolates of Cladophora vagabunda(L) VAN DEN HOEK which came from different latitudes (Table 1 and Figure 1) have been employed in this study. All isolates

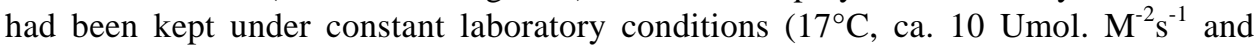
16:8) for several of years.

Growth rates of the isolates were measured as follows : Apical fragments consist- 
ing of ca. 12 cells were cut off and placed singly in sterile plastic petridishes $(9 \mathrm{~cm}$ in diameter) containing ca. $20 \mathrm{ml}$ of provasoli's enriched seawater medium which was renewed every 5 days. The cultures were incubated in controlled environment incubators (Fridina) at $5^{\circ} \mathrm{C}$ temperature intervals ranging from $5^{\circ}$ to $35^{\circ} \mathrm{C}\left(\right.$ all $\left.+1{ }^{\circ} \mathrm{C}\right)$, at an irradiance of $40 \mathrm{Umol} . \mathrm{M}^{-2} \mathrm{~s}^{-1}$ and a $16: 8$ photoperiod. Philips Tl $20 \mathrm{~W} / 33$ Rs fluorescent tubes were used as a light source. Five replicates of each isolate were incubated at each experimental temperature.

\section{Tabel 1. Isolates of $C$, vagabunda}

\begin{tabular}{lllll}
\hline $\begin{array}{l}\text { Location } \\
\text { site }\end{array}$ & $\begin{array}{l}\text { Years of } \\
\text { Collec. }\end{array}$ & $\begin{array}{l}\text { Code of } \\
\text { isolate }\end{array}$ & $\begin{array}{l}\text { Genetic } \\
\text { status }\end{array}$ & Habitat \\
\hline $\begin{array}{l}\text { Eastern Atlantic } \\
- \text { Roscoff, France (ROS) }\end{array}$ & 1983 & V 83.17 & n & $\begin{array}{l}\text { Penze estuary midlittoral } \\
\text { intertidal pools }\end{array}$ \\
$\begin{array}{l}\text { Meditteranean } \\
- \text { Corsica (COR) }\end{array}$ & 1984 & V 84 34 & 2n & Open coast, lowlittoral \\
$\begin{array}{l}\text { Western Atlantic } \\
- \text { Curacao (CUR) }\end{array}$ & 1984 & V 84 10 & n & Open coast, lowlittoral \\
$\begin{array}{l}\text { Eastern Indian Ocean } \\
- \text { Western Australia (WAT) }\end{array}$ & 1985 & V 85 23 & n & Lagoon \\
\hline
\end{tabular}

* Based on number of flagella of zooids i.e. 2 and 4 flagella for $n$ and 2n, respectively.

The cultures were gradually brought to the experimental conditions in steps of $5^{\circ} \mathrm{C}$ each lasting for at least several days. The isolates were observed and drawn with a camera Lucida at 2-3 day intervals for up to 2-3 weeks. The total length was measured with a HP 9874 AA digitizer. The relative growth rate (RGR) during exponential growth was calculated using the following formula :

$$
R G R=\frac{\ln L_{t 2}-\ln L_{t 1}}{12-t 1} \times 100 \% \mathrm{day}^{-1}
$$

where $\mathrm{L}_{\mathrm{tl}}$ and $\mathrm{L}_{\mathrm{t} 2}$ are the length on days tl and $\mathrm{t} 2$, respectively.

Survival tests were done with single plants of ca. $5 \mathrm{~cm}$ long which were placed in sterile glass tubes containing $20 \mathrm{ml}$ of medium. Three replicates of each isolate were incubated under each experimental condition. Survival potential at low temperature 


\section{HATTA and BREEMAN}

was tested in a waterbath at $0^{\circ}+0,1^{\circ} \mathrm{C}$ at irradiance of 10 and $20 \mathrm{Umol} . \mathrm{m}^{-2} \mathrm{~s}^{-1}$ and a $8: 16$ photoperiod. Survival potential at high temperature was tested at $35^{\circ}+0,5^{\circ} \mathrm{C}$ in a controlled environment incubator. (Maurius) at irradiances of 10 an 20 Umol. $\mathrm{M}^{-2} \mathrm{~s}^{-1}$ and a 16: 8 photoperiod. Observations were made every 3-4 days and the medium was renewed every 6 and 4 days for $0^{\circ}$ and $35^{\circ} \mathrm{C}$, respectively. Plants which showed signs of damage after a given period of incubation were immediately removed to higher or lower temperatures and than gradually brought (in steps each lasting for at least 5 days) to temperature of $20^{\circ} \mathrm{C}$ (at $40 \mathrm{Umol} . \mathrm{m}^{-2} \mathrm{~s}^{-1}$ and $16: 8$ photoperiod) to test for their regrowth capability.

\section{RESULTS}

\section{Relative Growth Rates}

The four isolates showed differences in their growth responses over the temperature range of $10^{\circ}$ up to $35^{\circ} \mathrm{C}$ (Figure 2). None of the isolates grew at $5^{\circ} \mathrm{C}$ but they remained, alive. A rapid increase in the RGR was shown by two isolates (from W. Australia and Roscoff) over the temperature range of $10^{\circ}-20^{\circ} \mathrm{C}$, and over a shorter temperature range $\left(10^{\circ}-15^{\circ} \mathrm{C}\right)$ by the Corcsican isolate, whereas the increase was more gradual in the Curacao isolate (between $10^{\circ}-20^{\circ} \mathrm{C}$ ).

Apparently the Roscoff isolate had a narrower temperature growth span than the other isolates i.e. between $10^{\circ}-30^{\circ} \mathrm{C}$, whereas the others grew between $10^{\circ}-35^{\circ} \mathrm{C}$. The Roscoff isolate* achieved its optimum between $20^{\circ}-30 \mathrm{C}$ with a maximum RGR of $75.14 \%$ day $^{-1}$ at $30^{\circ} \mathrm{C}$, which decreased drastically to $0 \%$ day $^{-1}$ at $35^{\circ} \mathrm{C}$. At this temperature cell bleaching was apparent after 10 days in culture. Sporulation occurred at temperature of $20^{\circ}, 25^{\circ}$ and $30^{\circ}$ after 6,8 and 4 days incubation, respectively. The W. Australian isolate grew between $10^{\circ}-35^{\circ} \mathrm{C}$, and its optimum was achieved between $25^{\circ}-35^{\circ} \mathrm{C}$, with a maximum RGR of $73.07 \%$ day $^{-1}$ at $30^{\circ} \mathrm{C}$. Sporulation occurred at temperature of $20^{\circ}, 25^{\circ}$, $30^{\circ}$ and $35^{\circ}$ after $7,4,4$ and 5 days incubation, respectively. Although the Curacao isolate had a slower increase in RGR at temperature between $10^{\circ}-25^{\circ} \mathrm{C}$, this isolate had a similar growth curve as the W. Australian isolate. Growth occurred between $10^{\circ}-35^{\circ} \mathrm{C}$, and its optimum was achieved between $25^{\circ}-35^{\circ} \mathrm{C}$ with a maximum of $49.61 \%$ day $^{-1}$ at $25^{\circ} \mathrm{C}$. Sporulation was observed only one once in a single replicate at $25^{\circ} \mathrm{C}$ after 6 days incubation. The Corsican isolate displayed the lowest maximum RGR of $35,52 \%$ day $^{-1}$ at $20^{\circ} \mathrm{C}$, but it had the broadest optimum i.e. between $15^{\circ}-30^{\circ} \mathrm{C}$. Sporulation occurred at $10^{\circ} \mathrm{C}$ after 6 days and at $20^{\circ}, 25^{\circ}$ and $30^{\circ} \mathrm{C}$ after 4 days incubation.

Univariate analysis of variance showed that temperature, isolate and interaction between these two factors were all significant sources of variation in the RGR (Table 2). Pairwise comparisons amongst isolate (Student's t-test) at each temperature treatment were presented in Figure 2. 


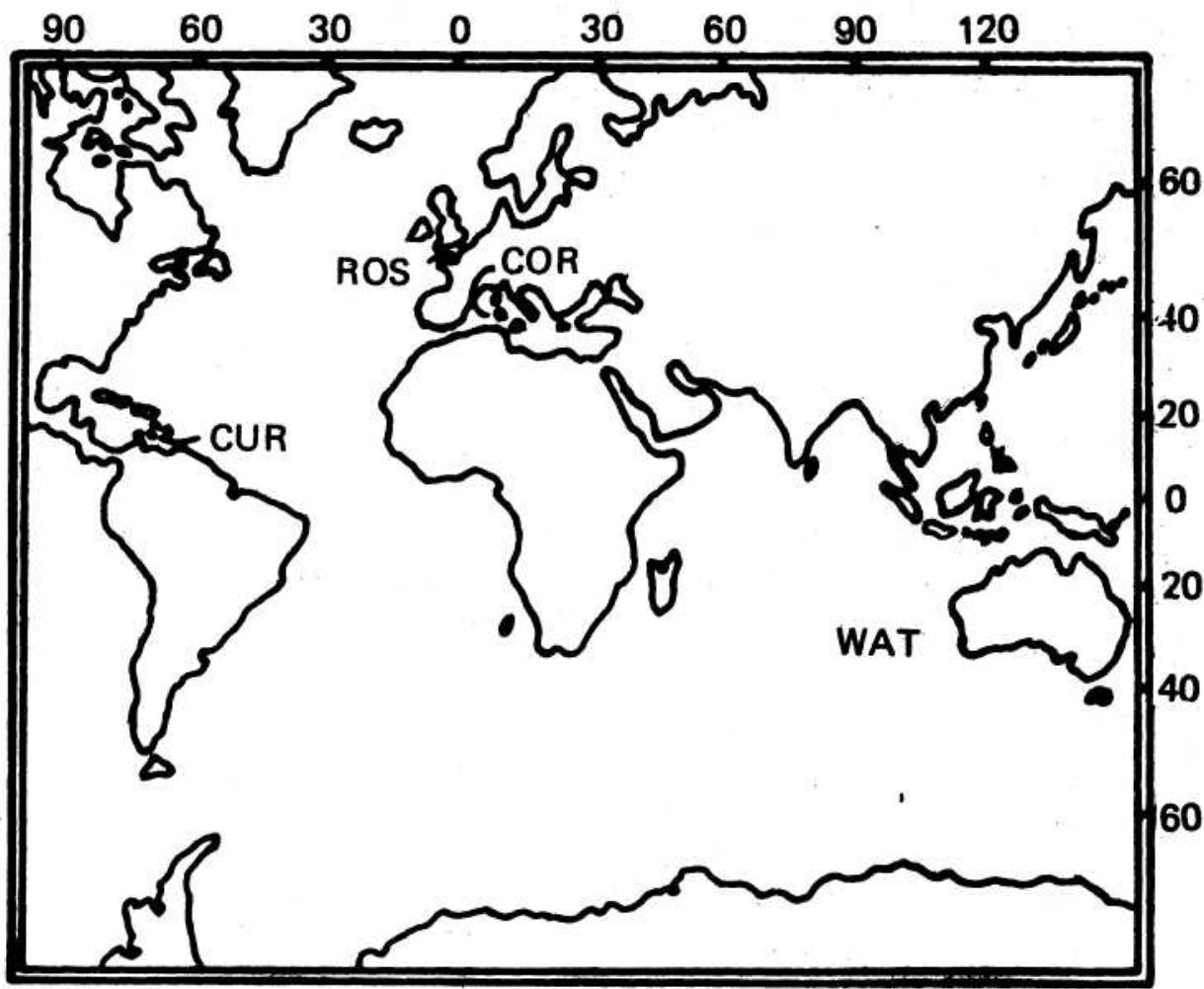

Figure 1. Location of collection sites of Cladopora vagabunda isolates. Abbreviation refer to isolates codes (table 1).

Table 2. Anova of RGR between $10^{\circ}$ and $35^{\circ} \mathrm{C}$ of four irotates of Cladophora vagabunda.

\begin{tabular}{|l|rr|c|c|c|}
\hline $\begin{array}{l}\text { Sources of } \\
\text { variation }\end{array}$ & \multicolumn{1}{|l|}{$\begin{array}{l}\text { Sum of } \\
\text { squares }\end{array}$} & Df & \multicolumn{1}{l|}{$\begin{array}{l}\text { Mean of } \\
\text { squares }\end{array}$} & F value & $\begin{array}{l}\text { Signi- } \\
\text { ficance }\end{array}$ \\
\hline Temperature (T) & 28563.77 & 5 & 5712.75 & 5.01 & @ \\
Isolate (I) & 10751.13 & 3 & 3581.71 & 64.01 & @@ \\
T X I & 17104.59 & 15 & 1140.31 & 20.38 & @ \\
Error & 5371.24 & 95 & 55.95 & - & \\
(Total) & 61790.73 & 119 & - & - & \\
\hline
\end{tabular}

@ and @@ = significant at 99\% level. 
HATTA and BREEMAN

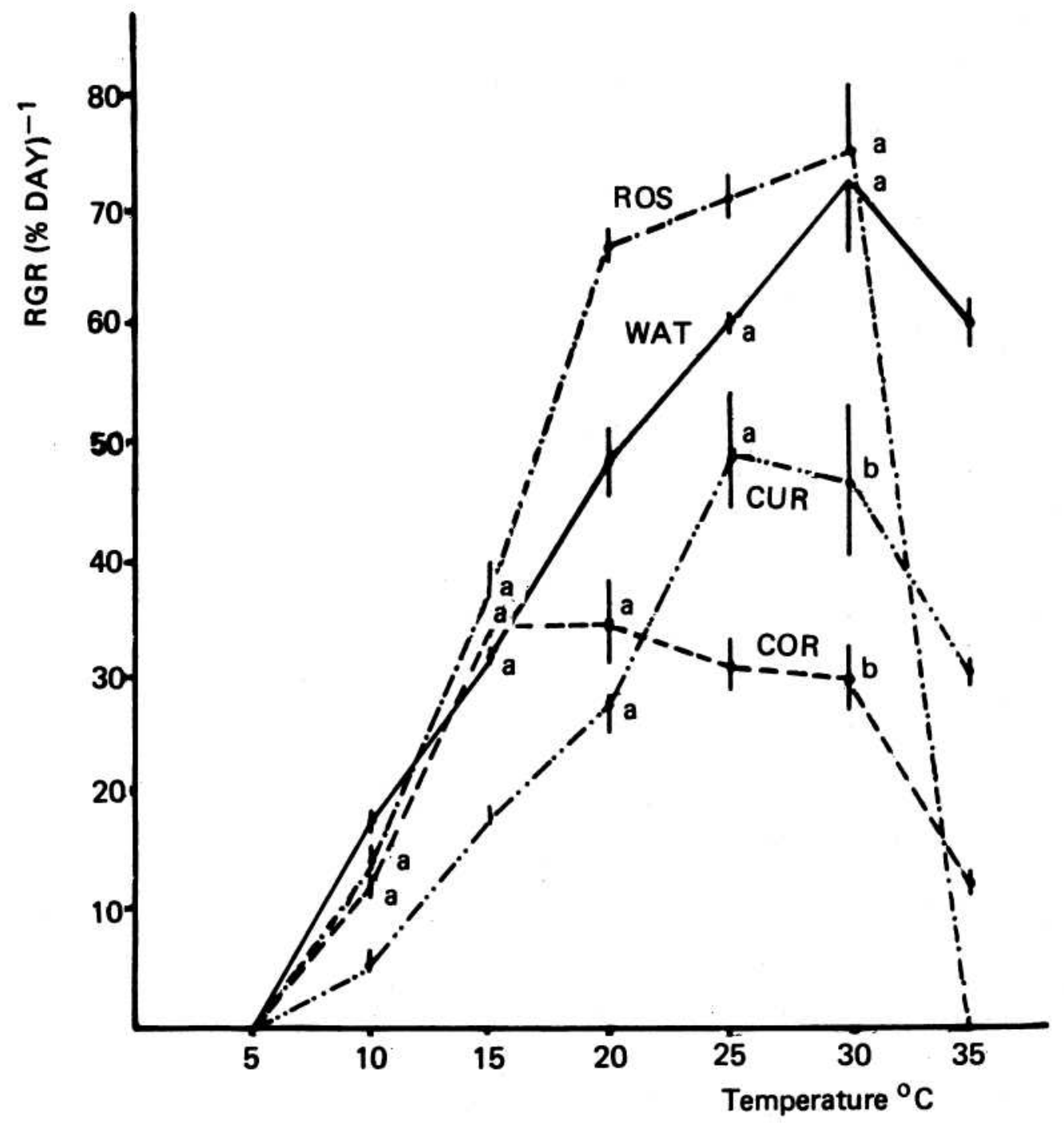

Figure 2. Relative growth rates of Cladophone vaqabunda isolates at various temperatures. Vertical bars represent $95 \%$ confidence limit of mean RGR. Similar letters indicate nonsignificant differences (Student's t-test). Isolatecodes are explained in table 1. 


\section{Ecotypic Variation}

\section{Survival Test}

As displayed in Figure 3, the W. Australian isolate was the most succesfull in withstanding temperature stress. This isolate survived at $35^{\circ} \mathrm{C}$ at 10 and $20 \mathrm{Umol}$. $\mathrm{M}^{-2} \mathrm{~s}^{-1}$ for more than 60 days, and at $0^{\circ} \mathrm{C}$ it survived for 34 and 60 days at 10 and $20 \mathrm{Umol} . \mathrm{m}$ $\mathrm{s}^{-1}$, respectively. Isolates at $35^{\circ} \mathrm{C}$ i.e. about 19 days at both irradiances.. At $10^{\circ} \mathrm{C}$ the Corsican isolate also survived for 60 days at both irradiances, while the Roscoff isolate

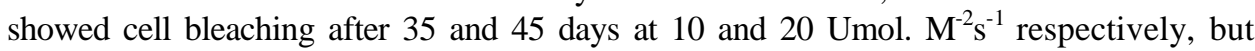
subsequently recovered at a higher temperature $\left(20^{\circ} \mathrm{C}\right)$. At $35^{\circ} \mathrm{C}$, the Curacao isolate survived for 60 days at $10 \mathrm{Umol} . \mathrm{M}^{-2} \mathrm{~s}^{-1}$, whereas at $20 \mathrm{Umol}$. $\mathrm{M}^{-} \mathrm{s}^{-1}$ it showed cell bleaching after 37 days but recovered at $20^{\circ} \mathrm{C}$. At $0^{\circ} \mathrm{C}$ damage was observed after 37 and 30 days at 10 and $20 \mathrm{Umol} . \mathrm{M}^{-2} \mathrm{~s}^{-1}$, respectively, but recovery occurred at $20^{\circ} \mathrm{C}$.

\section{DISCUSSION}

As displayed in Figure 2, the Gadophora vagabunda isolates all showed considerable plasticity in growth rates over a wide temperature range, in accordance with the wide temperature variation occuring over its distribution range (Figure 4). None of the isolates exhibited specific adaptation to local temperature conditions (Figure 5), and all of the isolates demonstrated basically the same character i.e. a eurythermic response with growth occurring between $10^{\circ}-30 / 35^{\circ} \mathrm{C}$, limited growth at $5^{\circ} \mathrm{C}, 10^{\circ} \mathrm{C}$ being the lowest temperature permitting growth and optimum growth rates occurring at high temperature between $25^{\circ}-30^{\circ} \mathrm{C}$. Thus, all of the $\mathrm{C}$ vagabunda isolates obviously still have a certain degree of genetic similarity in theirthermal characteristics.

Furthermore in Figures 2 and 5, same variation in RGRs among the isolates has been shown and statistically proved (Table 2). Such variations apparently are common in widely distributed marine algal, for examples in Ectocarpus siliculosus fBOLTON, 1983) and Laminaria spp. (BOLTON and LUNING, 1982). The rapid growth of the W, Australian and Roscoff isolates at temperature higher than those experienced in nature shows that these isolates grow under suboptimal conditions in their original habitats. The very broad range of optimum temperature of the Corsican isolate, comparable to that a Dumontia contorta (Rhodophyta) isolate from the Netherlands (RIETEMA and VAN DEN HOEK, 1984), is in accordance with their occuring i.e. in habitats with broadest local temperature ranges. The Curacao isolate demonstrated optimum growth at temperature coinciding with the local temperature range.

Based on survival for at least 30 days, such as was suggested by VAN DEN HOEK (1982), to test the survival ability of seaweeds, Cladophora vagabunda showed variation between isolates from different collecting sites. At the lower stress temperature $\left(0^{\circ} \mathrm{C}\right)$, no differences between isolates were apparent. But at the higher stress temperature $\left(35^{\circ} \mathrm{C}\right)$ the isolates could be divided into two groups, one group tolerating this high temperature represented by the W. Australian and Curacao isolates, and second group 


\begin{tabular}{|c|c|}
\hline \multirow{2}{*}{ ISOLATES } & Survival at $0^{\circ} \mathrm{C}$ ( days) \\
\hline & $\begin{array}{lllllll}0 & 10 & 20 & 30 & 40 & 50 & 60\end{array}$ \\
\hline WAT - U8523 & 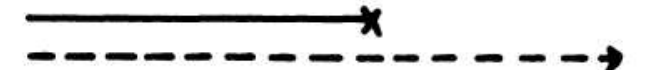 \\
\hline CUR - U8410 & $\overline{------1}$ \\
\hline COR - U8434 & 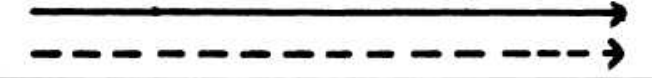 \\
\hline ROS - U8317 & $\overline{-------1}--1$ \\
\hline ISOLATES & Survival at $35^{\circ} \mathrm{C}$ (days) \\
\hline & $\begin{array}{lllllll}0 & 10 & 20 & 30 & 40 & 50 & 60 \\
\end{array}$ \\
\hline WAT - U8523 & $----------\rightarrow$ \\
\hline CUR - U8410 & 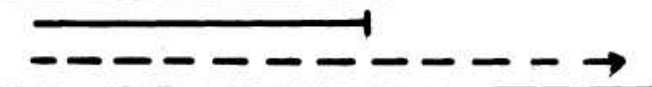 \\
\hline COR - U8434 & $---\dot{x}$ \\
\hline ROS - U8317 & $\overrightarrow{-a x}$ \\
\hline
\end{tabular}

Figure 3. Survival capability of the isolates at stress temperatures. Solid and dotted lines represent irradiances of 20 and $10 \mathrm{Umol} . \mathrm{m}^{-2} \mathrm{~s}^{-1}$, respectively. $---\mathrm{x}$ is plants damaged and unable to recover at $20^{\circ} \mathrm{C},---1$ is damage which observed after $n$ days but the plants recovered at $20^{\circ} \mathrm{C}, \ldots-$ means growth continued until the end of the experiment $(60$ days). 


\section{Ecotypic Variation}

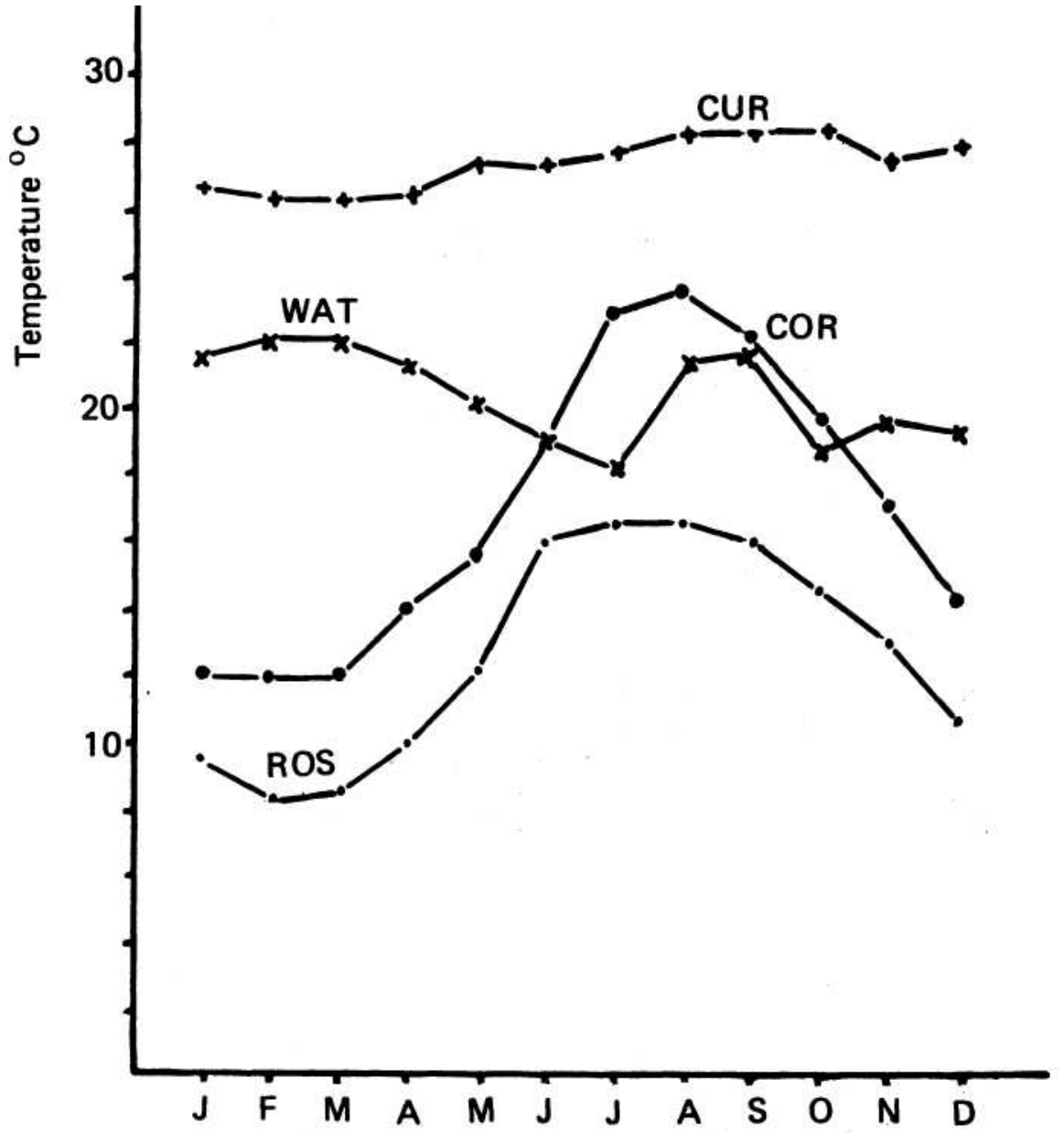

Figure 4. Annual temperature fluctuations on the adjacent open coast near the collection sites of the four Cladophora vaqabunda isolates (Source : GORSKOV, 1978). 


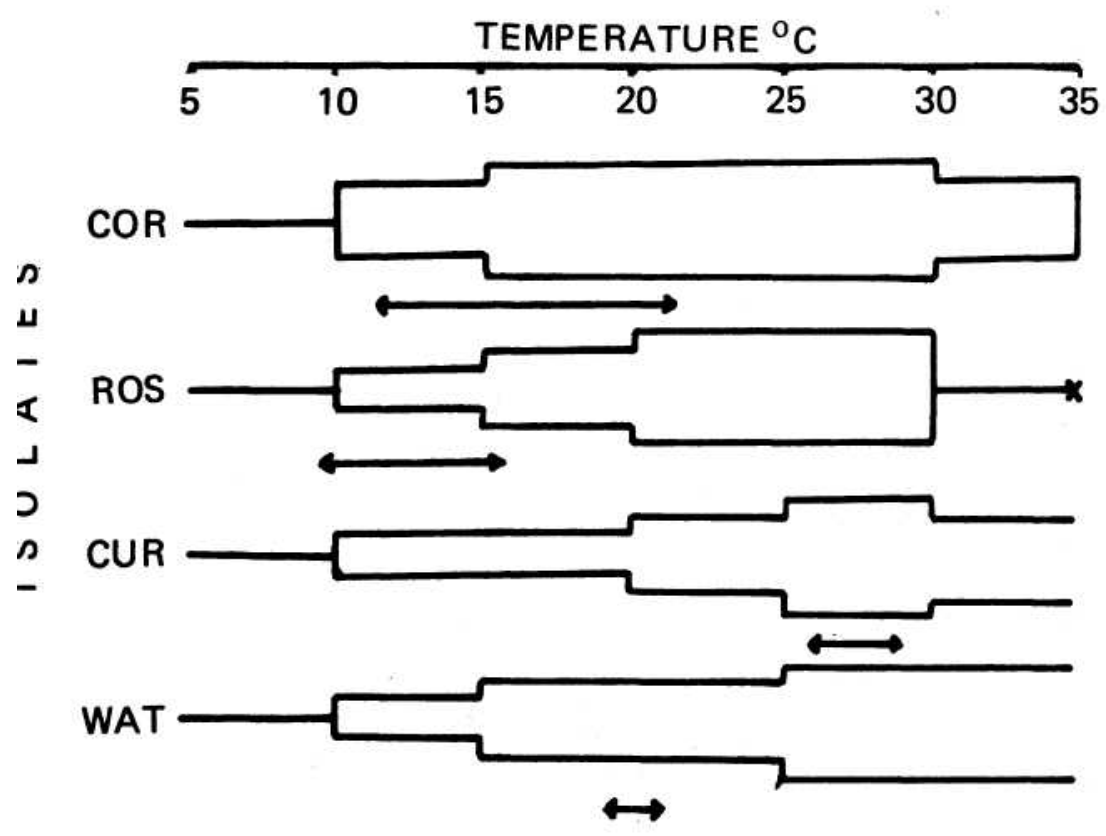

Figure 5. Comparison of growth responses of the four Qadophora vaqabunda isolates with annual temperature ranges at their collection sites. Bar diagrams represent growth rates from maximum ( $80 \%$ of maximum RGR) to appreciable growth (20-50\% of maximum RGR). Single lines indicate survival but no growth. $\mathrm{X}$ is death within 3 weeks, arrows (Bellow) represent annual temperature ranges of seawater on open coast near collection sites. 


\section{Ecotypic Variation}

not tolerating this high temperature represented by the Corsican and Roscoff isolates. The reduction of the maximum survival temperature on algal which invaded the cold temperature waters has been previously described by LUNING (1984) with North Atlantic algal as an example. This phenomenon has earlier been reported by BBEBL (In : BOLTON, 1983) with the speciesPlocamium cartilagineum (I) Dixon (asP. Coccineum var pacificum (Kylin) Dawson) which occurs in Europe and the Pacific coast of North America. BOLTON (1983) also clearly demonstrated difference in maximum survival temperature in Ectocarpus siliculosus from widely different latitudes. Even in European regions such differences could be found in Laminaria saccharina with maximum survival temperature of $22^{\circ} \mathrm{C}$ in a Helgoland isolate and of $23^{\circ} \mathrm{C}$ in isolates from the Isle of Man and Brittany (BOLTON and LUNING, 1982). Thus, the present data for Cladophora vagabunda are quite similar. These differences in maximum survival temperature can be considered as genetical adaptation of the isolates to tropical temperature condition.

In conclusion, as a consequence of the eurythermal temperature response of all isolates, the wide grographical distribution of $C$. vagabunda is primarily by nongenetical adaptation. However, increased survival capability of the tropical isolates at $35^{\circ} \mathrm{C}$ and some differences in the temperature growth-curves show that some genetically based adaptation also occurs. Nevertheless, this genetic adaptation has not been sufficient for the development of ecotypes which are optimally adapted to the local condition.

\section{ACKNOWLEDGEMENTS}

The first author gratefully wishes to thank Prof. Dr. C. van den Hoek who gave an opportunity and involved him into the Tropical Marine Algae Research Project conducted by Biology Centre of State University of Groningen. The authors also thank Mr. Sujatno Birowo MSc for reading the manuscript.

\section{REFERENCES}

BOLTON, J.J., 1983. Ecoclinal variation in Ectocarpus siliculosus (Phaeophyceae) with respect to temperature growth optima and survival limits. Mar. biol 73 : 131-138.

BOLTON, J.J. and K. LUNING, 1982. Optimal growth and maximal survival temperatures of Atlantic Laminaria spp. (Phaeophyta) in culture. Mar. biol 66 : 89-94.

Cambridge, M., AM. Breeman, R. van Ossterwijk and C van den Broek, 1984. Temperature responses of some North Atlantic Cladophora species (Chlorophyceae) in relation to their geographical distribution. Helgolander Meerswtters, 38 : 349-363.

ESP1NOZA, J. and AR.O. CHAPMAN, 1983. Ecotype differentiation of Laminaria longicruris in relation to seawater nitrate concentration. Mar. biol. $74: 212-218$.

GORSHKOV, S.G, 1978. World Ocean Atlas. VoL 2. Atlantic and Indian Oceans. Pergamon Press. Pp. 128-139. 


\section{HATTAandBREEMAN}

GREGOR, J.W., 1944. The Ecotype. Biol. rev. 19 : 20-30.

HOEK, V. VAN DEN, 1979. The phytogeography of Cledophora (Chlorophyceae) in the Northern Atlantic Ocean in comparison to that of the other benthic algae species. Helgolander Wiss. Meesesunten, 32 : 374-393.

HOEK, C VAN DEN, 1982. The distribution of benthic marine algae in relation to the temperature regulation or their life histories. Biol. J. linn. soc. $18: 81$ - 144.

HOEK, C VAN DEN and HB.S. WOMERSLEY, 1984. The genus Cladophora Kuetzing. 1983 : 262 noun. cons, in : The marine benthic flora of Southern Australia. H.B.S. Womersley (ed.). Part 1,185-213.

INNES, D.J., 1984. Genetic differentiation among populations of marine algae. Helgol. Meere-sunters, 38 :401 -417.

LUNING, K., 1984. Temperature tolerance and biogeography of seaweeds. The marine algae flora of Helgoland (Northsea) as an example. Helgolander Meeresunters, 38 : 305-317.

RIETMA, H and C VAN DEN HOEK, 1984. Search for possible latitudinal ecotype in Dumontia contarta (Rhodophyta). Helgolander Meeresunters, 38 : 389-399. 